\title{
PENGARUH NILAI MATEMATIKA TERHADAP HASIL BELAJAR EKONOMI SISWA KELAS X iis SMA NEGERI 17 SURABAYA
}

\author{
Moch.Burhan.Sidqi \\ Program Studi S1 Pendidikan Ekonomi, Fakultas Ekonomi, Universitas Negeri Surabaya \\ Email: Moch.Sidqi @mhs.unesa.ac.id \\ Lucky Rachmawati \\ Program Studi S1 Pendidikan Ekonomi, Fakultas Ekonomi, Univeritas Negeri Surabaya \\ Email: Luckyrachmawati@unesa.ac.id
}

\begin{abstract}
ABSTRAK
Penelitian ini bertujuan untuk mengetahui pengaruh nilai matematika terhadap hasil belajar mata pelajaran ekonomi siswa kelas X IIS SMA Negaeri 17 Surabaya. Penelitian ini merupakan jenis penelitian eksplanatori yang bertujuan untuk menganalisis hubungan-hubungan antara satu variabel dengan variabel lainnya atau bagaimana suatu variabel mempengaruhi variabel lainnya. Variabel tersebut adalah variabel nilai matematika dan variabel hasil belajar mata pelajaran ekonomi.Penelitian ini untuk mengetahui variabel nilai matematika terhadap hasil belajar mata pelajaran ekonomi. Pendekatan penelitian ini menggunakan pendekatan kuantitatif. Populasi yang digunakan yaitu seluruh siswa kelas X IPS SMA Negari 17 Surabaya. Karena data yang akan diambil adalah Pengambilan data dalam penelitian ini adalah nilai rapor matematika dan nilai ulangan dan rapor mata pelajaran ekonomi pada smester ganjil 2017-2018.Dari penelitian ini diharapkan mendapatkan gambaran tentang ada tidaknya pengaruh nilai matematika terhadap hasil belajar mata pelajaran ekonomi.Dari hasil uji regresi linier sederhana diketahui bahwa nilai matematika mempunyai pengaruh yang positif terhadap hasil belajr ekonomi siswa Kelas Xiis 1,2,dan 3. Dengan demikian berarti apabila nilai matematika siswa itu baik, maka hasil belajar ekonomi peserta didik akan mendapatkan hasil belajar yang baik, begitu juga sebaliknya apabila nilai matematika kurang baik maka akan mendapatkan hasil belajar ekonomi yang kurang baik.
\end{abstract}

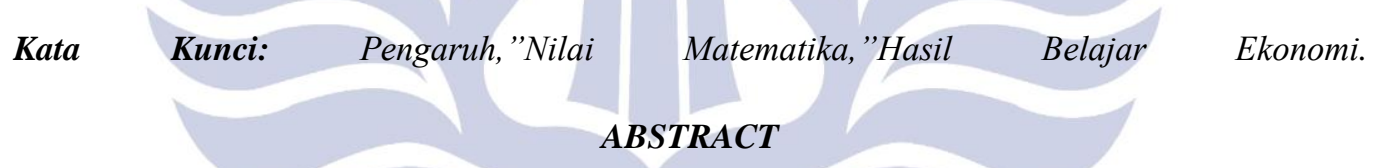

The study aims to determine the effect of mathematical values on the value of economic subjects in class $X$ of the IIS SMA Negaeri 17 Surabaya. This research is a type of explanatory research that aims to analyze the relationships between one variable with other variables or how a variable affects other variables. These variables are mathematical value variables and learning outcomes of economic subjects.To find out the mathematical value variable on the results of learning economic subjects. This research approach uses a quantitative approach. The population used is all students of class X IPS Negari 17 Surabaya High School. Retrieval of data in this study are math report scores and test scores and report cards on economic subjects in the odd semester 2017-2018. From this research, it is expected to get a picture of the influence of mathematical values on the results of learning economic subjects.

Keywords: influence," mathematical value," economic learning outcomes. 


\section{PENDAHULUAN}

Pada dasarnya tujuan pendidikan adalah untuk mencerdaskan kehidupan bangsa terutama untuk pengembangan potensi peserta didik seperti yang tercantum di dalam Undang-Undang Nomor 20 Tahun 2003 tentang Sisdiknas bahwa tujuan pendidikan adalah: “ Untuk mengembangkan potensi peserta didik agar menjadi manusia yang cerdas bermartabat, beriman dan bertaqwa kepada Tuhan Yang Maha Esa, berakhlaq mulia, sehat jasmani, berilmu, cakap, kreatif, mandiri, dan menjadi warga negara yang demokratis serta bertanggung jawab “

Dari rumusan tujuan pendidikan tersebut atas dapat disimpulkan bahwa melalui pendidikan diharapkan sumberdaya manusia Indonesia berkualitas sehingga dapat menjawab tantangan perkembangan zaman, namun tetap berakar pada nilai moral yang dianut oleh bangsa Indonesia. Untuk mendukung tujuan tersebut pemerintah telah melakukan berbagai usaha diantaranya mengembangkan sarana dan prasarana pendidikan disemua jenjang pendidikan.

Masalah yang sering menjadi sorotan para pakar baik dalam maupun luar negeri adalah masalah mutu pendidikan. Oleh sebab itu yang perlu dibenahi sistem pendidikan di Indonesia adalah bagaimana memperbaiki mutu pendidikan di semua jenjang mulai sekolah dasar sampai perguruan tinggi. Peningkatan mutu pendidikan sangat penting karena untuk menjamin kualitas sumber daya manusia. Sehubungan dengan itu perlu adanya berbagai usaha perbaikan terutama bagaimana meningkatkan kualitas pembelajaran di sekolah. Oleh sebab itu berbagai komponen yang berkaitan dengan pembelajaran perlu mendapat perhatian secara khusus, terutama kompetensi guru, kurikulum dan fasilitas yang mendukung seperti gedung sekolah, labor, dan perpustakaan. Untuk meningkatan kemampuan guru selama ini dengan mengadakan seminar, diklat, workshop, dan bahkan melanjutkan sekolah kejenjang lebih tinggi S2 maupun S3. Dengan demikian diharapkan akan meningkatkan kualitas pengajaran di sekolah. Untuk melihat kesuksesan pembelajaran di sekolah diantaranya dapat dilihat dari hasil belajar yang di capai oleh siswa, karena hasil belajar dijadikan tolok ukur untuk melihat samapai dimana peserta didik dapat menguasai bahan yang telah diajarkan oleh gurunya. Menurut Fathurrohman (2015) “ Hasil belajar meliputi tiga asapek dianataranya aspek kognitif, afektif dan psikomotor. Untuk mengetahui sejauh mana pemahaman siswa mengenai materi pelajaran yang sudah diberikan oleh guru dapat dilhat melalui hasil belajar dalam aspek kognitif. Pembelajaran yang berkualitas tergantung dari motivasi siswa, kreativitas dan kompentensi para pengajar"

Salah satu aktivitas pembelajaran di SMA Negeri 17 Surabaya adalah mata pelajaran ekonomi. Untuk menjelaskan mata pelajaran ekonomi kita perlu memahami tentang pengertian ekonomi. Menurut Winarno (2007) "Ilmu ekonomi merupakan ilmu yang membahas tentang usaha manusia dalam memproduksi, memasarkan atau mendistribusi serta kegunaan hasil usaha tersebut untuk memenuhi kebutuhan hidupnya".

Adapun tujuan mata pelajar ekonomi menurut Permen no.22 tahun 2006 tentang standarisasi kompetensi dasar adalah "untuk membentuk sikap bijak, rasional dan bertanggung jawab, karena dengan memiliki pengetahuan dan keterampilan ilmu ekonomi, manajemen, dan akuntasi yang bermanfaat bagi diri sendiri, rumah tangga, masyarakat dan negara".

Selain itu ekonomi mempunyai beberapa karakteristik, menurut Ekowati (2008) karakteristik itu dapat diuraiakan sebagai berikut:

“ a) Ilmu ekonomi merupakan fakta atau nyata, kenyataan bahwa kebutuhan manusia tidakada habis-habisnya, sedangkan sumber-sumber ekonomi 
untuk memenuhi kebutuhan manusia jumlahnya sangat terbatas $b$ ) Ilmu ekonomi mengembangkan teori-teori untuk menjelaskan fakta secara rasional, sistematis, obyektif dan mempunyai tujuan yang jelas. c) Umumnya, analisis yang digunakan dalam ilmu ekonomi adalah metode pemecahan masalah $d$ ) Inti dari ilmu ekonomi adalah memilih alternatif yang terbaik untuk mencapai kemakmuran manusia. e) Lahirnya ilmu ekonomi karena adanya kelangkaan sumber kebutuhan manusia”.

Dari uraian tersebut dapat disimpulkan bahwa mata pelajaran ekonomi merupakan mata pelajaran yang mempelajari tentang bagaimana manusia secara individu maupun kelompok secara bersama- sama berusaha untuk memenuhi kebutuhan hidupnya.

Ilmu ekonomi pada dasarnya ada kaitan yang erat dengan ilmu matematika, kaitan itu dapat dilihat dari aspek perhitungan dalam ilmu ekonomi seperti penggunaan bilangan bulat, pecahan, pengurangan, penamabahan, perkalian, dan pembagian. Menurut (Kalangi 2011, Sujono:1988) Ilmu ekonomi pada prinsipnya ilmu yang bersifat semi eksata, maka dalam memahami ilmu ekonomi memerlukan suatu analisis yang bersifat kuantitatif dan kualitatif . Analisa yang bersifat kualitatif ini dalam ilmu ekonomi memerlukan alat bantu ilmu matematika. Oleh karena itu siswa yang ingin memmpelajari ilmu ekonomi secara baik, dianjurkan mempelajari ilmu matematika sebagai dasarnya.

Dengan demikian dalam mempelajari dan memecahkan ilmu ekonomi diperlukan suatu persyaratan kemampuan dasar matematika, sehingga dapat diaplikasikan ke dalam pemecahan masalah ekonomi. Matematika dalam ilmu ekonomi digunakan sebagai alat untuk memahami penyajian dan pemahaman masalah ekonomi sehingga menjadi lebih sederhana untuk disajikan, dan dipahami.

Sehubungan dengan itu penelitian ini akan melihat hasil nilai mata pelajaran matematika dan ekonomi sebagai tolak ukur untuk mengetahui apakah nilai pelajaran matemaatika ada pengaruhnya terhadap hasil belajar mata pelajaran ekonomi.

Dari uraian dan penjelasan di atas maka peneliti ingin melihat tentang "Pengaruh Nilai Matematika Tehadap Hasil Belajar Mata Pelajaran Ekonomi Siswa Kelas X IIS SMA Negeri 17 Surabaya".

Menurut Slameto (2010) ada dua faktor yang mempengaruhi hasil belajar siswa yaitu:

\section{Faktor Internal.}

Faktor internal, merupakan faktor yang dominan berasal dari dalam yaitu faktor fisik dan psikologis. Faktor fisik seperti kesehatan badan, sedangkan faktor psikologis seperti minat, bakat, intelegensi, perhatian, dan motivasi.

Dengan demikian dapat dijelaskan bahwa hasil belajar seorang terdapat banyak faktor yang mempengaruhinya. Misalnya faktor kesehatan, anak yang mengalami gamgguan fisik karena sakit ataupun karena cacat tubuh baik akibat dari kecelakaan atau karena bawaan dari lahir akan mempengaruhi hasil belajar. Begitu pula dengan anak yang mempunyai intelegensi baik maka akan lebih mudah dan cepat menyerap pelajaran yang diajarkan begitu pula sebaliknya. Begitu pula halnya anak yang mempunyai perhatian yang hanya tertuju kepada suatu obyek, maka akan mendapatkan hasil belajar yang maksimal. Oleh sebab itu siswa harus konsentrasi penuh terhadap materi yang sedang dipelajarinya. Minat dan bakat anak terhadap bakat materi pelajaran akan mempengaruhi terhadap nilai hasil belajarnya, karena apabila materi yang dipelajari kurang sesuai dengan bakat dan minatnya, tentu hasil belajar tidak maksimal. Selain itu dalam belajar sangat diperlukan motivasi baik dari dalam maupun dari luar diri siswa. Motif merupakan daya penggerak atau pendorong 
seseorang untuk mencapai tujuan yang akan dicapai.

\section{Faktor eksternal,}

Yang termasuk faktor eksternal adalah faktor yang mempengaruhi hasil belajar yang berasal dari luar diri siswa diantaranya: faktor lingkungan keluarga, lingkungan sekolah, dan masyarakat. Lingkungan keluarga memberi pengaruh hasil belajar siswa dikarenakan keluarga merupakan lingkungan yang mempunyai peran pertama dan utama yang mendorong anak untuk belajar. Sedangkan lingkungan sekolah seperti guru, peraturan sekolah, ruangan kelas, perpustakaan, labor, dan sarana penunjang lainnya sangat menentukan hasil belajar. Lingkungan masyarakat dimana anak tinggal sangat mempengaruhi hasil belajar siswa dikarenakan beberapa hal diantaranya, keterlibatan anak dalam kegiatan di masyarakat, penggunaan teknologi informasi (HP) yang bebas, teman bergaul dan lain sebagainya.

\section{Hasil Belajar}

\section{a. Pengertian Belajar}

Banyak pendapat para ahli tentang belajar, secara umum belajar dapat diartikan sebagai bentuk usaha seseorang untuk mendapatkan ilmu pengetahuan atau prestasi yang baik di bidang akademik maupun non akademik. Menurut Rianto (2014) "Belajar adalah suatu usaha untuk berbuat sesuatu dengan cara melakukan berulang-ulang sehingga yang anak menjadi terbisa". Menurut Klien (Semiawan,2008:), (Muhibbin Syah:2006), “ Belajar adalah hasil pengalaman yang mempengaruhi tingkah laku manusia yang relatif permanen. Jadi, dalam pandangannya perubahan ditimbulkan oleh pengalaman tersebut baru dapat dikatan belajar apabila mempengaruhi organisme

Dari penjelasan di atas di atas dapat diambil kesimpulan bahwa belajar merupakan suatu proses yang kompleks yang memerlukan latihan-latihan secara terus menerus. Proses belajar itu bisa terjadi apabila adanya interaksi atau komunikasi antara seseorang dengan lingkungannya baik lingkungan sekolah, keluarga maupun masyarakat. Oleh karena itu, belajar dapat tidak memandang usia kapan saja bisa belajar dan dimana saja tempat belajar itu. Salah satu ciri seseorang itu telah belajar adalah adanya perubahan tingkah laku, baik pengetahuan, keterampilan dan sikap.

\section{b. Pengertian Hasil Belajar}

Menurut Djamarah (2006) mengemukakan bahwa hasil belajar merupakan hasil aktifitas baik secara individu maupun secara kelompok dalam rangka mengetahui sejauh mana proses belajar telah berhasil". Sedangkan menurut Suprijono (2014) pengertian hasil belajar adalah sebagai berikut:“ Hasil belajar merupakan adanya perubahan tingkah laku yang terjadi pada beberapa aspek kemampuan manusia secara menyeluruh yang terjadi yang meliputi kemampuan kognitif, afektif, dan psikomotor. Hasil belajar diperoleh karena hasil proses belajar mengajar dimana terjadinya interaksi antara guru dan siswa berdasarkan tujuan pengajaran yang telah ditetapkan".

Menurut Dimyati (2013) “ Hasil bealajar dapat dibedakan menjadi dua yaitu dampak dari proses belajar mengajar dan dampak pengiring. Dampak proses belajar mengajar adalah hasil belajar yang dapat diukur melalui hasil tes atau ujian yang diwujudkan dengan nilai angka dalam rapor, ijazah dan lain sebagainya.. Sedangkan dampak pengiring adalah aplikasi ilmu pengetahuan dibidang ilmu lain dari hasil belajar".

Sedangkan menurut Blom (Suprijono,2014) Hasil belajar mencakup tiga ranah yaitu:

\section{a. Ranah Kognitif}


Ranah kognitif ini meliputi, knowledge, comprehension, application, analisis, dan evaluation.

Ranah ini menyangkut tentang bagaimana anak mendapatkan pengetahuan baru tentang apa yang telah dipelajari. Dari pengetahuan tersebut anak dapat menjelaskan, meringkas, dan memahami terhadap pengetahuan yang diperoleh. Selain itu anak dapat menerapkan ide dan gagasan dalam kehidupan sehari hari. Dengan demikian anak akan timbul kreatifitas dan membuat perencanaan, pengorganisasian, serta memberikan penilai terhadap hasil kreatifitas tersebut.

\section{b.Ranah Afektiftif}

Ranah ini meliputi beberapa aspek dianataranya, karakterisasi, organisasi, dan responding.

Seorang anak yang telah belajar akan mengalami perubahan sikap terutama yang berkaitan dengan karakter ini dapat dilhat dari perilaku dalam pergaulan sehari hari. Selain itu anak yang telah melakukan belajar akan dapat mengelola konflik dan emosi serta muncul akan ketertarikan untuk partisipasi akatif dalam proses belajar mengajar.

Ranah Psikomotorik lebih mengarah kepada keterampilan fisik, produktif, dan teknik.Berdasarkan pengertian di atas dapat disimpulkan bahwa, hasil belajar merupakan perubahan dan pengalaman yang dialami oleh siswa setelah melakukan kegiatan proses belajar mengajar yang berkaiatan berbagai aspek pengetahuan, sikap dan keterampilan. Hasil belajar salah satunya dapat diukur melalui tes, wawancara, ulangan atau ujian yang diberikan guru dengan tujuan untuk mngetahui seberapa besar penguasaan dan pemahaman siswa terhadap materi yang sudah diajarkan.
4.. Pengaruh Nilai Matematika Terhadap Hasil Belajar Ekonomi

Menurut Masykur (2008) "Dalam mempelajari matematika diperlukan penalaran, logika, karena matematika dalam ilmu pengetahuan merupakan ilmu alat atau dasar untuk mempelajari ilmu lain. Maka untuk dapat mempelajari disiplin ilmu lainnya, yang perlu dilakukan adalah mengusai ilmu dasar yaitu matematika". Sedangkan Abdurrahman (2003) mengatakan bahwa “ Ilmu matematika dalam pembahasannya lebih banyak menggunakan bahasa simbolis yang mempunyai fungsi untuk menjelaskan bermacam hubungan kuantitatif, sedangkan fungsi secara teoritis adalah agar dapat memudahkan berfikir".

Sedangkan mata pelajaran ekonomi dalam analisanya juga menggunakan simbol dan angka, terutama pada materi keseimbangan pasar. Dalam disiplin ilmu pengetahuan ilmu ekonomi bisa menggunakan pendekatan matematik. Menurut Bumulo (2005) Manfaat pendekatan matematika dalam analisis ilmu adalah sebagai berikut:

“ 1. Hubungan hubungan antara berbagai faktor ekonomi dapat dinyatakan secara lebih singkat dan jelas. 2) Perubahan dari faktor faktor kuantitatif mudah dihitung dan dilukiskan dalam bentuk tabel. 3)Difinisi dan asumsi dapat dirumuskan secara jelas dan tegas. 4) Penarikan kesimpulan dalam proses analisis akan lebih sistematis sehingga kekeliruan dapat dihindarkan. 5) Penerapan matematika dalam ilmu ekonomi dapat menampakkan keterbatasan serta kemungkinan.”Dengan demikian dapat dikatakan bahwa memahami dan mempelajari ilmu matematika sangat penting apa bila ingin memahami disiplin lmu lain termasuk ilmu ekomi. 


\section{METODE}

Penelitian ini tidak meneliti semua populasi tapi hanya sampelnya saja. Untuk menentuan jumlah sampel pada peneltian ini dengan menggunakan Rumus Slovin sebagai berikut:

$$
\begin{array}{ll}
\mathbf{n}=\frac{\mathbf{N}}{\text { 1+N(e)2 }} & \\
\text { Keterangan: } & \\
\mathbf{n} & =\text { Besaran sampel } \\
\mathbf{N} & =\text { Besaran populasi } \\
\mathbf{E} & =\text { Batas toleransikesalahan }
\end{array}
$$

Dengan rumus tersebut diatas maka dapat ditentukan jumlah sampel sebagai berikut:

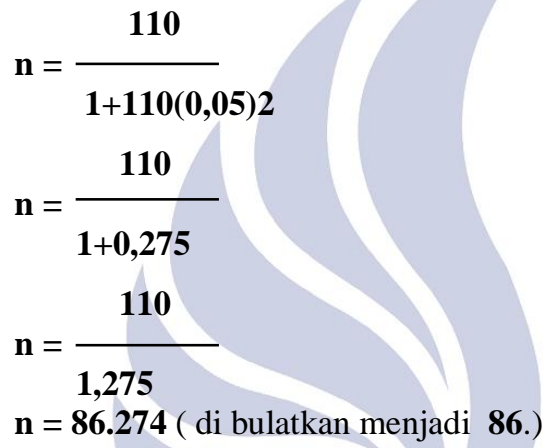

\section{Teknik Pengumpulan Data}

Teknik pengumpulan data merupakan cara yang digunakan untuk memperoleh suatu data yang akan digunakan dalam menyusun penelitian. Teknik pengumpulan data yang digunakan dalam penelitian ini menggunakan teknik dokumentasi yaitu cara pengumpulan data berdasarkan dokumen tertulis yang berupa data nilai mata pelajaran matematika dan ekonomi. Nilai tersebut dapat dilihat pada buku rapor. Oleh sebab itu dokumen yang diperlukan dalam penelitian ini adalah nilai rapor matematika dan ekonomi kelas X IIS SMA Negeri 17 Surabaya.

Teknik Analisis Data

Data yang terkumpul akan diolah dan dianalisis supaya dapat diambil suatu kesimpulan tentang data tersebut. Analisis data yang digunakan dalam penelitiaan ini adalah sebagai berikut :

\section{a. Analisis Statistik Deskriptif}

Teknik Analisis data statistik deskriptif dengan pendekatan kuantitatif untuk menjelaskan variable nilai matematika dan nilai ekonomi siswa kelas X IIS SMA Negeri 17 Surabaya.

\section{b. Analisis Regresi Sederhana}

Analisis data regeresi sederhana merupakan hubungan fungsional ataupun kasual satu variable independen dengan variable dependen Sugiono (2008). Untuk mengetahui seberapa besar variable bebas mempengaruhi variabel terikat dari persamaan regresi dinyatakan sebagai berikut:

$\mathbf{Y}=\mathbf{a}+\mathbf{b X}+\mathbf{e}$

Keterangan :

$\mathbf{X}=$ Nilai matematika

$\mathbf{Y}=$ Nilai mata pelajaran ekonomi

$\mathbf{A}=$ Konstanta, nilai $\mathrm{Y}$ bila $\mathrm{X}$

$\mathbf{B}=$ Koefisien regresi, yaitu angka yang menunjukan peningkatan atau penurunan variable dependen yang didasarkan pada variable independen. Jika b (+) maka terjadi kenaikan, jika (-) maka terjadi penurunan. $\mathrm{E}=$ Faktor pengganggu (Eror)

\section{HASIL DAN PEMBAHASAN}

\section{Hasil penelitian}

\section{Nilai Hasil Belajar Ekonomi}

Berdasarkan analisis data hasil belajar ekonomi nilai terendah yang dimiliki peserta didik sebesar 75 sedangkan untuk nilai tertinggi sebesar 86. dengan nilai tengah sebesar 82. Berikut adalah tabel penyajian datanya :Tabel 4.1 Hasil Belajar Ekonomi Kelas X iis

\begin{tabular}{|c|c|c|l|}
\hline No. & $\begin{array}{c}\text { Interva } \\
\mathbf{l}\end{array}$ & Frekuensi & \\
\hline 1 & $75-79$ & 8 & $9,3 \%$ \\
\hline 2 & $80-81$ & 27 & $31,4 \%$ \\
\hline 3 & $82-83$ & 22 & $25,6 \%$ \\
\hline 4 & $84-85$ & 25 & $29 \%$ \\
\hline
\end{tabular}




\begin{tabular}{|l|c|c|c|}
\hline 5 & $\begin{array}{r}86- \\
>86\end{array}$ & 4 & $4,7 \%$ \\
\hline \multicolumn{2}{|c|}{ Jumlah = } & $\mathbf{8 6}$ & $\mathbf{1 0 0 \%}$ \\
\hline
\end{tabular}

Sumber : Data diolah peneliti(2019)

Berdasarkan tabel 4.1 dapat dilihat untuk frekuensi dengan nilai terbanyak diperoleh pada kelas dengan interval nilai 80 81 dengan jumlah frekuensi $27(31,4 \%)$

Untuk mengetahui jumlah peserta didik yang mendapatkan nilai diatas KKM (Kriteria Ketuntasan Minimum), maka dapat dilihat pada tabel berikut:

Tabel 4.2 Klasifikasi hasil belajar ekonomi kelas X

\begin{tabular}{|c|c|c|}
\hline Nilai & Frekuensi & Persen (\%) \\
\hline $\mathrm{X}>75$ & 0 & $0 \%$ \\
\hline $\mathrm{X}<75$ & 86 & $100 \%$ \\
\hline Jumlah & 86 & $100 \%$ \\
\hline \multicolumn{2}{|c|}{ Sumber : Data diolah peneliti (2019) } \\
\hline
\end{tabular}

Berdasarkan tabel 4.2 diatas dapat diketahui bahwa Siswa kelas Xiis 1,2,dan,3 SMA Negeri 17 Surabaya memiliki nilai diatas KKM dengan Standarasisasi KKM sebesar 75.

2.Nilai Matematika.

Nilai matematika siswa kelas X IIS 1,2 dan 3 tertinggi sebesar 85 dan nilai terendah 72. Untuk lebih jelasnya dapat dilihat tabel berikut:

Tabel 4.3 Nilai matematika siswa kelas Xiis

\begin{tabular}{|c|c|c|c|c|}
\hline $\mathbf{N}$ & $\begin{array}{c}\text { Inter } \\
\text { val } \\
\text { nilai }\end{array}$ & $\begin{array}{c}\text { Klasifik } \\
\text { asi }\end{array}$ & Frekue & $\begin{array}{c}\text { Persent } \\
\text { ase }\end{array}$ \\
\hline 1 & $\begin{array}{l}86- \\
100\end{array}$ & $\begin{array}{c}\text { Sangat } \\
\text { Baik }\end{array}$ & 0 & $0 \%$ \\
\hline 2 & $81-85$ & Baik & 45 & 52,4 \\
\hline 3 & $76-80$ & $\begin{array}{c}\text { Cukup } \\
\text { Baik }\end{array}$ & 48 & $44,3 \%$ \\
\hline 4 & $<75$ & $\begin{array}{c}\text { Tidak } \\
\text { baik }\end{array}$ & 3 & $3.5 \%$ \\
\hline
\end{tabular}

Tabel 4.3 diatas menunjukan $0 \%$ peserta didik memiliki kemampuan matematika sangat baik,52,4\% baik,44,3\% cukup baik dan 3,5\% tidak baik dengan standarisasi KKM sebesar 75. Sehingga dapat diperoleh gambaran secara umum bahwa kemampuan matematika siswa kelas Xiis adalah baik.

\section{Uji Asumsi Klasik}

a.Uji Normalitas

Hasil Uji normalitas dilakukan dengan program aplikasi SPSS Versi 16.0.Cara pengambilan kesimpulan pada uji normalitas apabila diperloleh nilai Asymp. Sig.(2-tailed)> 0,05 (5\%) maka data residual tersebut terdistribusi normal. Melalui Uji One-sample kolomogrov smirnov test dapat diketahui nilai asump.sig (2-tailed) atau aumsi 2 arah sebesar 0,461 > (lebih besar dari 0,05 (5\%).Nilai tersebut menandakan bahwa data residual tersebar secara normal.

\section{b.Uji Heteroskedastisitas}

Uji heteroskedastisitas bertujuan untuk menguji apakah dalam model regresi linier terjadi ketidakcocokan terhadap variansi redidual dalam suatu pemantauan. Dalam penelitian ini uji heteroskedastisitas memakai metode uji Glejser. Metode ini dilakukan dengan cara meregresi ABS_RES (Absolut Residu) terhadap variabel bebas. .Cara pengambilan uji ini yaitu apabila diperoleh nilai siqnifikansi untuk variabel independen > 0,05 $(5 \%)$ dapat dinyatakan bahwa tidak terdapat gejala hekteroskedastisitas atau terjadi homoskedastisitas. Dari hasil uji Glejser diatas diperoleh nilai signifikansi sebesar $0,329>0,05$ yang menyatakan tidak 
terdapat heteroskedastisitas.atau bersifat homoskedastisitas.

\section{Analisi Regresi Linier Sederhana}

Analisis data penelitian ini menggunakan teknik analisis regresi linier sederhana. .Analisis regresi linier sederhana peneliti gunakan karena hanya ada satu variabel independen $\mathrm{x}$ (bebas). Hasil analisis linier sederhana diolah menggunakan SPSS Versi 16.0. Berikut ini adalah tabel hasil analisis regresi linier sederhana :

Tabel 4.6 Hasil analisis regresi linier sederhana Coefficients $^{\mathrm{a}}$

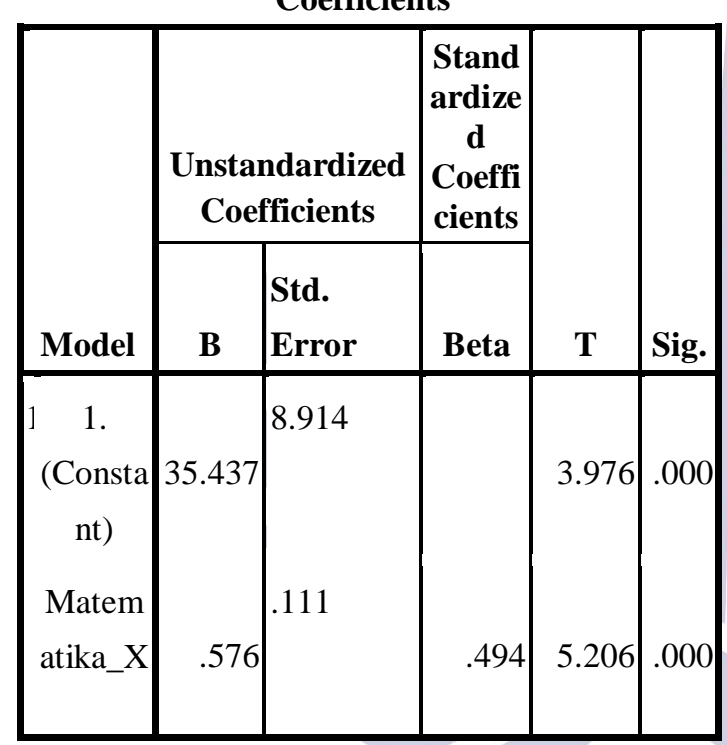

Sumber : Data diolah peneliti (2019)

Dari hasil pada tabel 4.6 maka ditentukan persamaan regresi linier sederhana sebagai berikut :

$$
Y=35,437+0,576 X
$$

Penjelasannya adalah jika nilai matematika (x) naik sebesar 1 (satuan), maka nilai ekonomi (y)akan bertambah sebesar $\mathbf{0 , 5 7 6}$.

\section{Koefisien Determinasi (R-square)}

Koefisien determinasi (R-square) dipakai untuk mengetahui seberapa jauh pengaruh kemampuan matematika terhadap nilai ekonomi.yang bersarnya adalah dari nol sampai satu. Dalam olah data nilai koefisien determinasi (R-square) dilakukan menggunakan SPSS Versi 16.0.Data determinasi koefisien (R-square) dapat dilihat pada tabel di mode summary.dari tabel tersebut diperoleh $R$ square sebesar 0,244 yang menunjukan bahwa $24,4 \%$ hasil belajar ekonomi dipengaruh ioleh kemampuan matematika.Sedangkan $75,6 \%$ dipengaruhi oleh variabel bebas lainya diluar penelitian.

\section{Uji Hipotesis}

Uji hipotesis dalam peneliitian ini yaitu menggunakan uji t.Uji digunakan untuk melihat pengaruh variabel bebas secara parsial ke variabel terikat.. Pengambilan kesimpulan dalam uji t yaitu apabila nilai nilai coefficien signifikansi $<0,05$ (5\%),maka menolak Ho yang berarti terdapat pengaruh signifikan antara kemampuan matematika terhadap hasil belajar ekonomi.Pengujian uji t dilakukan dengan bantuan SPSS Versi 16.0. Hasil uji t pada penelitian ini dapat di lihat tabel 4.7 yang menyimpulkan bahwa nilai signifikansi matematika sebesar $0,00<0,05$ yang berarti menolak H0,maka secara parsial kemampuan matematika berpengaruh signifikan terhadap hasil belajar ekonomi.

\section{Pembahasan}

Dari hasil uji regresi linier sederhana diketahui bahwa nilai matematika mempunyai pengaruh yang positif terhadap hasil belajr ekonomi siswa Kelas Xiis 1,2, dan 3. Dengan demikian berarti apabila nilai matematika siswa itu baik, maka hasil belajar ekonomi peserta didik akan mendapatkan hasil belajar yang baik, begitu juga sebaliknya apabila nilai matematika kurang baik maka akan mendapatkan hasil belajar ekonomi yang kurang baik. Hal ini sesuai dengan pendapat Sujono (1990) Apabila ingin mempelajari ilmu ekonomi secara baik harus mempelajari ilmu matematika karena sifat ilmu ekonomi mendekati ilmu eksata. Selain itu untuk mempelajari dan memahami ilmu ekonmi diperlukan 
analisis yang bersifat kualitatif dan kuantitatif. Untuk menganalisis ilmu ekonomi terutama yang bersifat kualitatif memerlukan alat bantu yaitu ilmu matematika (kalangi ,2011: 1) Sehubungan dengan itu untuk dapat mempelajari disiplin ilmu lainnya, yang perlu dilakukan adalah mengusai ilmu dasar yaitu matematika”.Masykur (2008). Penelitian ini memiliki kesamaan dengan hasil penelitian penelitian terdahulu yang dilaksanakan oleh Fajriah (2015) dengan judul "Pengruh Hasil Belajar Matematika Terhadap Hasil Belajar Akuntansi Kelas X AK di SMK Negeri 3 Pontianak. Hasil penelitian tersebut dimana kemampuan matematika terdapat hubungan yang positif dengan hasil belajar akuntansi. Hanya saja yang membedakan dengan penelitian ini adalah variable bebasnya.

\section{KESIMPULAN}

Berdasarkan analisis maka dapat disimpulkan bahwa kemampuan matematika memiliki pengaruh signifikan pada hasil belajar ekonomi siswa kelas Xiis 1,2 dan3 SMA Negeri Surabaya.Sebab matematika adalah cabang ilmu terapan yang dimana memiliki hubungan dan digunakan di berbagai aspek bidang keilmuan lainya.Dan didalam matapelajaran ekonomi matematika memiliki peranan penting dalam penyelesaian rumus" keseimbangan pasar,penentuan skala prioritas,perpajakan,dan materi lain yang berhubungan dengan rumus dan satuan hitung yang terdapat pada matematika.

\section{SARAN}

Berdasarkan hasil penelitian ini maka diperlukan beberapa saran sebagai berikut :Untuksiswa sebaiknya berlatih dan lebih giat untuk mempelajari matematika apabila ingin lebih mudah memahami dan mendapatkan nilai ekonomi yang lebih baik. Hal ini penting sebab ilmu ekonomi adalah ilmu terapan dan didalamnya terdapat bebagai macam teori dan simbol yang bisa dipermudah apabila kita mempelajari matematika dengan baik.Sedangkan
Bagi guru sebaiknya memberikan arahan dan pemahaman kepada siswa tentang rumus -rumus dasar ekonomi yang didalamya terdapat teori dasar matematika.dan memberikan pemahaman secara jelas tentang mata pelajaran ekonomi

\section{DAFTAR PUSTAKA}

Dimyati dan Mudjiyono. (2013). Belajar dan Pembelajaran. Rineka Cipta : Jakarta

Djamarah (2003) Psikologi Pendidikan. Rineka Cipta: Jakarta

Fajriyah, Anita Nurul (2015) Pengaruh hasil belajar matematika terhadap hasil belajar akuntansi siswa kelas X AK di SMK Negeri 3 Pontianak.

Kalangi, Bintang Josep (2011) Matematika Ekonomi dan Bisnis: Jakarta: Salemba Empat,)

Masykur,(2008). Mathematical Intelegence. Yogyakarta: AR-Ruzz Media.

Riyanto, Yatim (2014). Paradigma Baru Pembelajaran. Kencana: Jakarta

Ruseffendi, ET. 1988. Pengajaran Matimatika, Modern. Bandung: Tarsito.

Rusman. (2015). Pembelajaran Tematik Terpadu, Teori Praktik dan Penilaian. Grafindo: Jakarta

Masykur,(2008). Mathematical Intelegence. Yogyakarta: AR-Ruzz Media.

Slameto. (2010). Belajar dan Faktor-Faktor yang mempengaruhinya. Rikena CIpta: Jakarta

Semiawan, Conny R,. (2008) Belajardan Pembelajaran PraSekolah dan Sekolah Dasar ,. JAkarta :Macanan Jaya Cemerlang

Sugiyono (2008) Memahami Penelitian Kualitatif. Bandung: Alfabeta

Sugiyono(2016) Metode Penelitian Pendidikanpendekatan kuantitatif, kualitatif, R\&D. Bandung, Alfabeta

Sujono (1990) Pengajaran matematika untuk sekolah menengah:Jakarta, Departemen Pendidikan dan Kebudayaan Dikti. 
Winarno, Sigit (2003) Kamus Besar Ekonomi.

Bandung: Pustaka Grafika

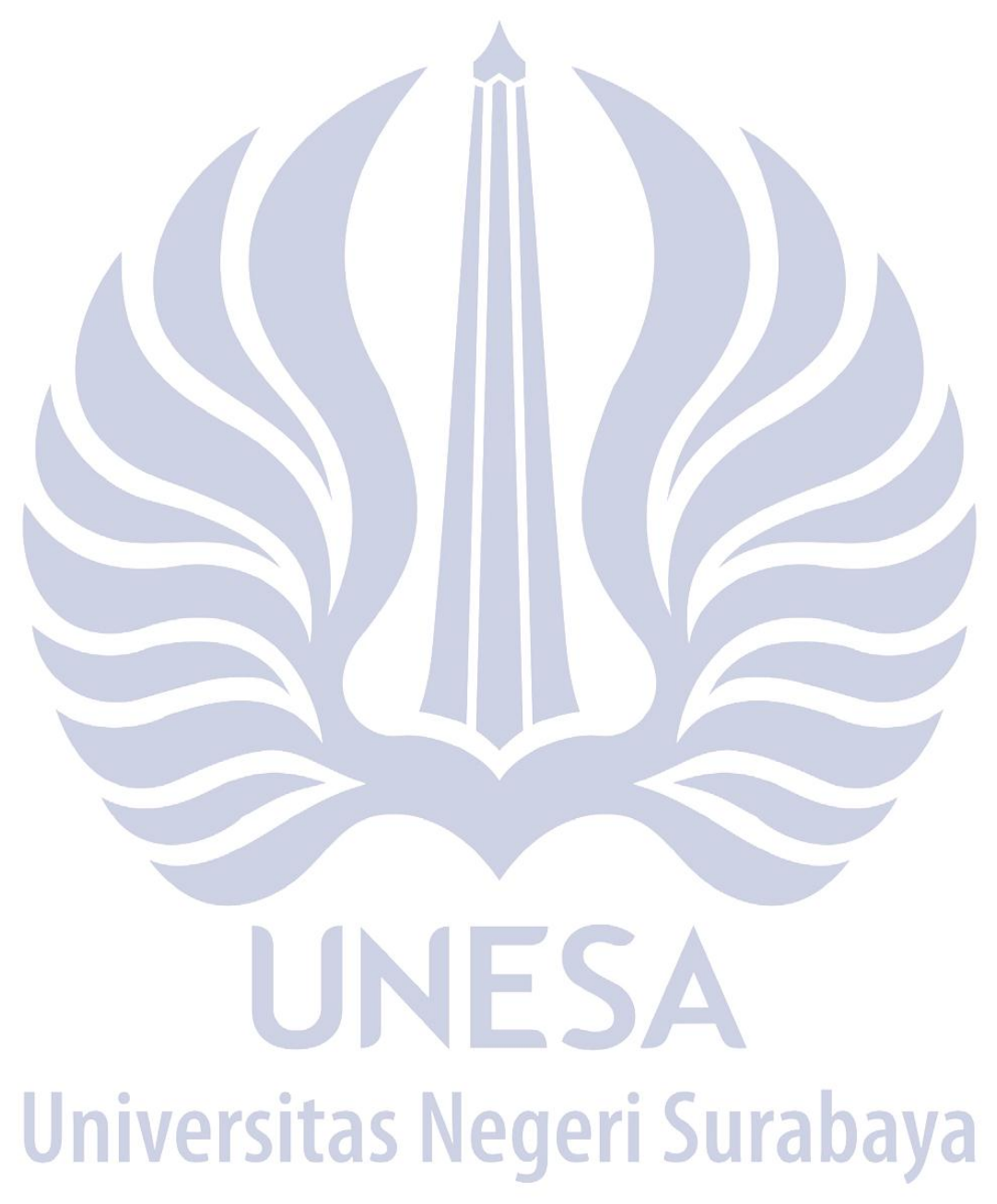

